\title{
Voltammetric Study and Thermodynamic Parameters of [Zn-L-Amino Acidate-Vitamin-PP] Complexes vis-à-vis Kinetics of Electrode Reaction
}

\author{
Farid Khan, Afroza Khanam \\ Electrochemical Laboratory, Department of Chemistry, Dr. H.S. Gour University, \\ Sagar - 470 003, Madhya Pradesh, Índia
}

\begin{abstract}
Voltammetric reduction of Zn (II) using L-lysine, L-ornithine, L-threonine, L-serine, Lphenylglycine, L-phenylalanine, L-glutamic acid, L-aspartic acid and vitamin-PP (nicotinamide, niacinamide) at $\mathrm{pH}=7.30 \pm 0.01$, and $\mu=1.0 \mathrm{M} \mathrm{NaClO}_{4}$ was reported at 25 and $35^{\circ} \mathrm{C}$. The nature of current voltage curves was quasireversible and diffusion controlled. Zn (II) formed 1:1:1, 1:1:2 and 1:2:1 complexes with these drugs as confirmed by Schaap and McMaster method. The sequence of stability constant of complexes L-lysine < L-ornithine < L-threonine < L-serine < L-phenylglycine < Lphenylalanine $<$ L-glutamic acid $<\mathrm{L}$-aspartic acid can be explained on the basis of size, basicity and steric hindrance of ligands. The thermodynamic parameters such as enthalpy $(\Delta \mathrm{H})$, free energy $(\Delta \mathrm{G})$ and entropy change $(\Delta \mathrm{S})$ have also been reported. The kinetic parameters viz. transfer coefficient $(\alpha)$, degree of irreversibility $(\lambda)$, diffusion coefficient (D) and standard rate constant (k) were calculated. The values of ' $\alpha$ ' confirmed the symmetric nature of 'activated complex' between oxidants and reductants response to applied potential between dropping mercury electrode and solution interface.
\end{abstract}

Keywords: voltammetry, thermodynamic parameters, electrode kinetics, [ $\mathrm{Zn}-\mathrm{L}$-amino acidate-vitamin-PP] complexes.

\section{Introduction}

Complexes of some metal ions with amino acids can be used as models to study the pharmaco-dynamic effects of drugs or for increasing the biocompatibility and minimize the toxic effects of some metal ions [1]. These L-amino acids are used

\footnotetext{
* Corresponding author. E-mail address: faridkhan58@yahoo.com; farid.fk@ rediffmail.com
} 
in many biological processes in human beings. On the other hand, L-amino acids are also involved in intracellular metabolism and operate specific transport systems of the plasma membrane, they do not affect cardiac function under normal conditions [2]. However, there is a growing body of evidences that certain of them may be vital for myocardial function and survival during ischemia / reperfusion stress. In this respect glutamic acid and aspartic acid seem to be the most important [3]. The invention provides the use of zinc complexes of selected amino acids from D- or L- isomers of proline, lysine, histidine, glycine, arginine and tryptophan and other pharmacologically acceptable salts of zinc. The use of the compound comprises administering an effective amount of said compounds for inhibition of growth: of the malarial parasite, plasmodium falciparum [4]. Vitamin-PP is water-soluble vitamin B-complex, a derivative of niacin. This drug is used in the prevention and treatment of diabetes; it also protects the vital pancreatic cells from diabetes inducing factors [5]. The niacin nucleotides $\mathrm{NAD}^{+}$(nicotinamide adenine dinucleotide) and $\mathrm{NADP}^{+}$ (nicotinamide adenine dinucleotide phosphate) serve as coenzymes in a large number of reversible oxidation-reduction systems [6, 7]. Therefore, the Zn complexes of these drugs have great importance. The concentrations of zinc in vivo can be reduced by drug therapy, but the specificity of drug and its amount is stability constant dependent [8]. Therefore, the authors have undertaken the present study to determine the stability constants, thermodynamic and kinetic parameters of these ternary complexes with the selected drugs polarographically, for which no reference has so far been traced out in the literature.

\section{Experimental}

\section{Instrumentation}

Electrochemical experiment, i.e., a simple DC polarography, was carried out using a manual polarograph with a Toshniwal PL-50 polyflex galvanometer. The polarographic cell was of Laitinen and Lingane type in which a polarographic capillary of $5.0 \mathrm{~cm}$ in length with $0.04 \mathrm{~mm}$ in diameter was used. The $\mathrm{m}^{2 / 3} \mathrm{t}^{1 / 6}$ value was $2.40 \mathrm{mg}^{2 / 3} \mathrm{~s}^{-1 / 2}$ at $60.02 \mathrm{~cm}$ effective height of mercury. A Systronic $\mathrm{pH}$ meter 361 was used to measure the $\mathrm{pH}$ of the analyte at $7.30 \pm 0.01$.

\section{Reagents}

The following chemicals were used in the experiments: $\mathrm{HClO}_{4}$ (Sigma), $\mathrm{NaOH}$ (Sigma), $\mathrm{NaClO}_{4}$ (Fluka), Triton X-100 (Sigma), $\mathrm{ZnCl}_{2}$ (B.D.H.), L-amino acids (Lobachem) and vitamin-PP (Fluka), and their solutions were prepared in double distilled water. The purity of L-amino acids was checked by chromatographic method [9]. Pure nitrogen gas was passed through the analyte for deoxygenation before recording the current-voltage data. The $\mathrm{pH}$ of the analyte at $7.30 \pm 0.01$ was adjusted by using dilute solutions of $\mathrm{HClO}_{4}$ or $\mathrm{NaOH}$ as required. Potassium dihydrogen phosphate- sodium hydroxide buffer was added to stabilize the $\mathrm{pH}$ of the analyte. 


\section{Voltammetric procedure}

Polarographic studies of the ternary complexes of $\mathrm{Zn}$ (II) with some amino acids and vitamin-PP were recorded using depolarizer and ligands (L-amino acids and vitamin-PP) in ratio 1:40:40 and the concentration of amino acids varied from 0.5 $\mathrm{mM}$ to $30.0 \mathrm{mM}$ at two fixed concentrations of vitamin-PP, i.e., $0.025 \mathrm{M}$ and $0.050 \mathrm{M}$. It has been observed that $\mathrm{E}_{1 / 2}$ shifted to more negative side with increase in concentration of L-amino acids. Current-voltage curves were obtained at different $\mathrm{pH}$ values. It has been observed that the maximum negative shift of $\mathrm{E}_{1 / 2}$ was obtained within the $\mathrm{pH}$ range $7.10-8.50$, but $\mathrm{pH} 7.30$ was selected for studying the complexes which are compatible to human blood $\mathrm{pH}$ [10]. The concentrations of metal, $\mathrm{NaClO}_{4}$ and Triton X-100 (suppressor) in test solutions were $0.5 \mathrm{mM}, 1.0 \mathrm{M}$ and $0.001 \%$, respectively.

\section{Results and discussion \\ Polarographic studies}

$\mathrm{Zn}$ (II) gave two electron quasireversible reduction waves at $\mathrm{pH}=7.30 \pm 0.01, \mu$ $=1.0 \mathrm{M} \mathrm{NaClO}_{4}$ at $25{ }^{\circ} \mathrm{C}$ [11]. The nature of current-voltage curves for complexes is also quasireversible. The $\mathrm{E}_{1 / 2}$ values became more negative with addition of vitamin-PP $(0.025 \mathrm{M}$ and $0.050 \mathrm{M})$ to the [ $\mathrm{Zn}-\mathrm{L}$-amino acids] system which showed ternary complex formation of $1: 1: 1,1: 1: 2$ and 1:2:1 complexes. Gelling [12] method was used to determine the values of $\mathrm{E}_{1 / 2}$ reversible from $E_{1 / 2}$ quasireversible by plotting ( $\left.E-R T / n F \log i_{d}-i / i\right)$ vs. $i$ for all the complexes. To know the values of $\beta_{11}$ and $\beta_{12}$, the study has been carried out at two constant concentrations of vitamin-PP i.e. $0.025 \mathrm{M}$ and $0.050 \mathrm{M}$. The values of stability constant of complexes, given in Table 1, were obtained by using the Schaap and McMaster [13] method (Fig. 1).

Table 1. Stability constants of binary and ternary complexes, $\mathrm{Zn}$ (II) $=0.5 \mathrm{mM}, \mu=1.0$ $\mathrm{M} \mathrm{NaClO}_{4}, \mathrm{pH}=7.3 \pm 0.01$, Temperature $=25^{\circ} \mathrm{C}$.

\begin{tabular}{cccccccccc}
\hline Ligands & $\log \beta_{\mathbf{0 1}}$ & $\log \beta_{\mathbf{0 2}}$ & $\log \beta_{\mathbf{0 3}}$ & $\log \beta_{\mathbf{1 0}}$ & $\log \beta_{\mathbf{2 0}}$ & $\log \beta_{\mathbf{3 0}}$ & $\log \beta_{\mathbf{1 1}}$ & $\log \beta_{\mathbf{1 2}}$ & $\log \beta_{\mathbf{2 1}}$ \\
\hline L-lysine & - & - & - & 3.80 & 6.50 & 9.25 & 4.37 & 7.20 & 9.98 \\
L-ornithine & - & - & - & 3.93 & 6.58 & 9.42 & 4.53 & 7.42 & 10.20 \\
L-threonine & - & - & - & 4.25 & 7.36 & 9.55 & 4.68 & - & 10.38 \\
L-serine & - & - & - & 4.38 & 7.42 & 9.68 & 4.84 & 7.75 & 10.60 \\
L-phenylglycine & - & - & - & 4.42 & 7.58 & 9.78 & 5.15 & 8.00 & 10.72 \\
L-phenylalanine & - & - & - & 4.50 & 7.62 & 9.97 & 5.31 & 8.22 & 10.94 \\
L-glutamic acid & - & - & - & 5.30 & 8.72 & 10.00 & - & 8.96 & 10.98 \\
L-aspartic acid & - & - & - & 5.45 & 8.95 & 10.25 & 5.76 & 9.18 & 11.20 \\
vitamin-PP & & & & & & & & & \\
(nicotinamide) & 1.91 & 2.90 & 3.30 & & & & & & \\
\hline
\end{tabular}



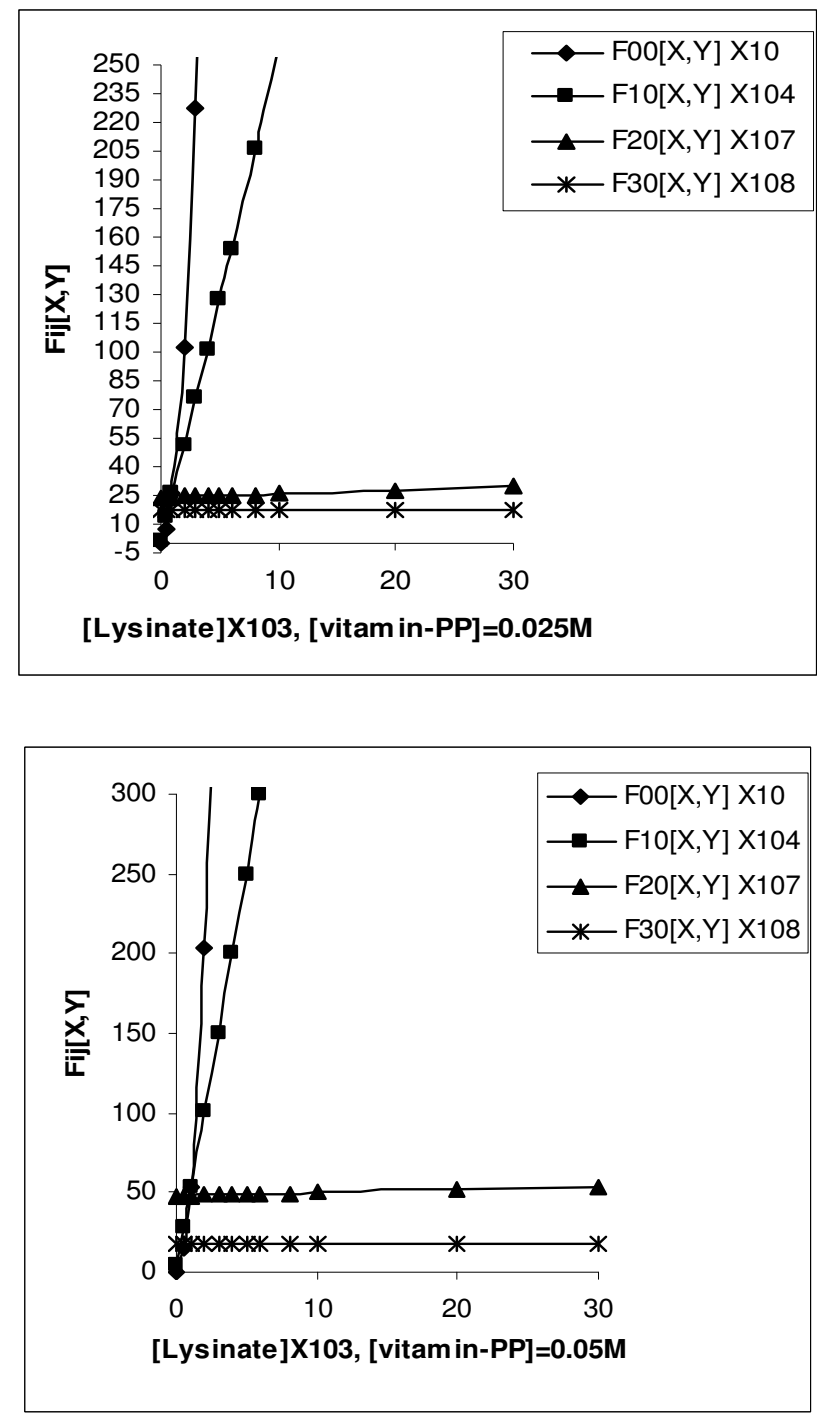

Figure 1. Plot of Fij[X, Y] vs. [X] for [Zn-L-lysinate-vitamin-PP] system.

\section{Comparison of stability of binary and ternary complexes}

To compare the stability of binary and ternary complexes, the values of mixing constant $\log \mathrm{K}_{\mathrm{m}}$ were calculated by the following equation [13]:

$$
\log \mathrm{K}_{\mathrm{m}}=\log \beta_{11}-1 / 2\left[\log \beta_{02}+\log \beta_{20}\right]
$$

Values of $\log \mathrm{K}_{\mathrm{m}}$ are $-0.33,-0.21,-0.45,-0.32,-0.09,0.05,-11.62,-0.16$, respectively, for [Zn-L-lysinate-vitamin-PP], [Zn-L-ornithinate-vitaminPP], [Zn-

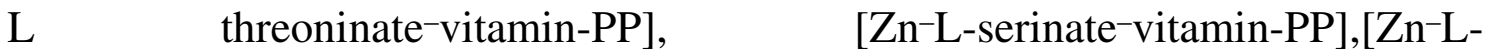
phenylglycinate-vita-min-PP], [Zn-L-phenylalaninate-vitamin-PP], [Zn-Lglutamate-vitamin-PP] and [Zn-L-aspartate-vitamin-PP] complexes. The positive values of $\log \mathrm{K}_{\mathrm{m}}$ indicate that the ternary complexes are more stable than the binary complexes, while the negative values indicate that the binary complexes are more stable than the ternary ones. 


\section{Trend of stability of ternary complexes}

The sequence of stability constants of complexes with respect to ligands is L-lys $<$ L-orn < L-thr < L-ser < L-phg < L-phe < L-glu < L-asp. It has been observed that as the size of amino acids increased the stability of its complexes decreased [14]. The stability of L-amino acid complex also depends upon the chelate ring formation and basicities of ligands [15]. In this study, the stability of lysinate complex is minimum owing to the lowest $\mathrm{pK}$ value of L-lysine, as expected [16]. In case of L-serine and L-threonine, the stability of the latter is less than the Lserine complex owing to the fact that electron withdrawing $\mathrm{OH}^{-}$group is nearer to L-threoninate complex than L-serinate complex, causing greater repulsive forces between metal and $\mathrm{OH}^{-}$group in L-threonine complexes than L-serine complexes. The higher stability of L-aspartate complexes than L-glutamate ones is obvious from the chelate ring formation; in these amino acids, the aspartate forms one five and one six-membered ring with the metal, while L-glutamate forms one six and one seven-membered ring. As the size of the ring in amino acid increases, the stability of complex decreases [17]. The stabilities of Lglutamate and L-aspartate complexes are greater than those of the L-lysinate, L-

ornithinate, L-threoninate, L-serinate, L-phenylglycinate, L-phenylalaninate complexes, due to the large difference in their basic strength [18]. The same is evident from $\mathrm{pK}$ values of L-amino-acids [19].

In the case of vitamin-PP, $\mathrm{N}$ - atom of pyridine group and $\mathrm{O}$ - atom of amide group may take part in bond formation with $\mathrm{Zn}$ (II), forming a six-membered ring [20].

It is clear from the values of stability constants of the complexes that vitamin-PP and amino acids used either singly or simultaneously might be effective to reduce the toxicity of metal in vivo.

\section{Thermodynamic parameters}

The kind of complex species that reduces on a mercury electrode depends on thermodynamic aspects [21]. Thermodynamic parameters such as enthalpy change $(\Delta H)$, free energy change $(\Delta G)$ and entropy change $(\Delta S)$ of the complexes have been calculated by the following equation [22]:

$$
\begin{gathered}
\Delta \mathrm{H}=2.303 \mathrm{R} \mathrm{T}_{1} \mathrm{~T}_{2}\left(\log \beta_{2}-\log \beta_{1}\right) / \mathrm{T}_{2}-\mathrm{T}_{1} \\
\Delta \mathrm{G}=-2.303 \mathrm{RT} \log \mathrm{K} \\
\Delta \mathrm{G}=\Delta \mathrm{H}-\mathrm{T} \Delta \mathrm{S}
\end{gathered}
$$

It is clear from the values of $\Delta S, \Delta G$ and $\Delta H$ in Table 2 that the stability constants $\left(\log \beta_{1}\right)$ and $\left(\log \beta_{2}\right)$ decreased with increase of temperature, confirming that complexes are not stable at higher temperature [23]. The values of $\Delta \mathrm{S}$ are more negative at higher temperature and $\Delta \mathrm{G}$ are less negative at higher temperature, confirming that complexes are not stable at higher temperature [24]. The negative values of $\Delta \mathrm{H}$ show that these reactions are exothermic in nature [25]. 
Table 2. Thermodynamic parameters of ternary complexes of [Zn-aminoacidate-vitamin-PP] system.

\begin{tabular}{|c|c|c|c|c|c|c|c|c|c|c|c|c|}
\hline \multirow{3}{*}{ System } & \multicolumn{3}{|c|}{ Stability constants } & \multicolumn{3}{|c|}{ - $\Delta$ H kcal./mole } & \multicolumn{3}{|c|}{ - $\Delta$ G kcal./mole } & \multicolumn{3}{|c|}{ - $\Delta \mathrm{S}$ cal./degree/mole } \\
\hline & $\log \beta_{11}$ & $\log \beta_{12}$ & $\log \beta_{21}$ & $\log \beta_{11}$ & $\log \beta_{12}$ & $\log \beta_{21}$ & $\log \beta_{11}$ & $\log \beta_{12}$ & $\log \beta_{21}$ & $\log \beta_{11}$ & $\log \beta_{12}$ & $\log \beta_{21}$ \\
\hline & $25^{\circ} \mathrm{C} / 35^{\circ} \mathrm{C}$ & $25^{\circ} \mathrm{C} / 35^{\circ} \mathrm{C}$ & $25^{\circ} \mathrm{C} / 35^{\circ} \mathrm{C}$ & \multicolumn{3}{|c|}{$\begin{array}{l}\left(35^{\circ} \mathrm{C}-25^{\circ} \mathrm{C}\right) \\
\text { for difference of } 10^{\circ} \mathrm{C}\end{array}$} & $25^{\circ} \mathrm{C} / 35^{\circ} \mathrm{C}$ & $25^{\circ} \mathrm{C} / 35^{\circ} \mathrm{C}$ & $25^{\circ} \mathrm{C} / 35^{\circ} \mathrm{C}$ & $25^{\circ} \mathrm{C} / 35^{\circ} \mathrm{C}$ & $25^{\circ} \mathrm{C} / 35^{\circ} \mathrm{C}$ & $25^{\circ} \mathrm{C} / 35^{\circ} \mathrm{C}$ \\
\hline [Zn- L-lysinate & 4.37 & 7.20 & 9.98 & \multirow{2}{*}{11.340} & \multirow{2}{*}{10.080} & \multirow{2}{*}{21.840} & 5.9591 & 9.8183 & 13.6093 & 18.0573 & 0.8788 & 27.6214 \\
\hline -vitamin-PP] & 4.10 & 6.96 & 9.46 & & & & 5.7785 & 9.8094 & 13.3329 & 18.0575 & 0.8792 & 27.6220 \\
\hline [Zn-L-ornithinate ${ }^{-}$ & 4.53 & 7.42 & 10.20 & \multirow{2}{*}{14.238} & \multirow{2}{*}{13.532} & \multirow{2}{*}{16.892} & 6.1773 & 10.1213 & 13.9123 & 27.0501 & 11.4475 & 10.0015 \\
\hline vitamin- PP ] & 4.19 & 7.10 & 9.80 & & & & 5.9067 & 10.0067 & 13.8121 & 27.0504 & 11.4479 & 10.0022 \\
\hline [ Zn-L-threoni nate & 4.68 & - & 10.38 & \multirow{2}{*}{20.160} & \multirow{2}{*}{-} & \multirow{2}{*}{15.960} & 6.3819 & - & 14.1547 & 46.2367 & - & 6.0590 \\
\hline -vitamin- PP ] & 4.20 & - & 10.00 & & & & 5.9194 & - & 14.0940 & 46.2370 & - & 6.0596 \\
\hline$\left[\mathrm{Zn}^{-} \mathrm{L}\right.$-serinate ${ }^{-}$ & 4.84 & 7.75 & 10.60 & \multirow{2}{*}{18.480} & \multirow{2}{*}{11.340} & \multirow{2}{*}{16.472} & 6.6001 & 10.5683 & 14.4577 & 39.8668 & 2.5902 & 6.7617 \\
\hline vitamin-PP ] & 4.40 & 7.48 & 10.21 & & & & 6.2013 & 10.5423 & 14.3899 & 39.8671 & 2.5907 & 6.7623 \\
\hline [ Zn-L- & 5.15 & 8.00 & 10.72 & \multirow{3}{*}{8.400} & \multirow{3}{*}{12.600} & \multirow{3}{*}{15.540} & 7.0228 & 10.9092 & 14.6184 & 4.6219 & 5.6745 & 3.0937 \\
\hline phenylglycinate & 4.95 & 7.70 & 10.35 & & & & 6.9765 & 10.8523 & 14.5872 & 4.6223 & 5.6750 & 3.0944 \\
\hline -vitamin-PP ] & & & & & & & & & & & & \\
\hline [ Zn-L-phenylalannate & 5.31 & 8.22 & 10.94 & \multirow{2}{*}{13.86} & \multirow{2}{*}{12.26} & \multirow{2}{*}{16.89} & 7.2410 & 11.2120 & 14.9214 & 22.2124 & 3.5311 & 6.6153 \\
\hline -vitamin-PP ] & 4.98 & 7.93 & 10.54 & & & & 7.0188 & 11.1765 & 14.8550 & 22.2127 & 3.5316 & 6.6159 \\
\hline [ Zn-L-glutamate & - & 8.96 & 10.98 & \multirow{2}{*}{-} & \multirow{2}{*}{15.120} & \multirow{2}{*}{16.800} & - & 12.2183 & 14.9729 & - & 9.7381 & 6.1322 \\
\hline -vitamin-PP ] & - & 8.60 & 10.58 & & & & - & 12.1208 & 14.9114 & - & 9.7387 & 6.1329 \\
\hline [ $\mathrm{Zn}^{-} \mathrm{L}_{\text {-aspartate }}^{-}$ & 5.76 & 9.18 & 11.20 & \multirow{2}{*}{15.960} & \multirow{2}{*}{16.052} & \multirow{2}{*}{16.892} & 7.8546 & 12.5213 & 15.2759 & 27.2003 & 11.8502 & 5.4255 \\
\hline vitamin-PP ] & 5.38 & 8.80 & 10.80 & & & & 7.5825 & 12.4027 & 15.2215 & 27.2006 & 11.8508 & 5.4262 \\
\hline
\end{tabular}




\section{Kinetic parameters}

The kinetic parameters, viz., transfer coefficient $(\alpha)$, degree of irreversibility $(\lambda)$, and standard rate constant $(\mathrm{k})$, determined by Tamamushi and Tanaka method $[46,47]$ by plotting $\left(E-R T / n F \log i_{d}-i / i\right)$ against $i$ and $\log (Z-1)$ against $\left(E_{1 / 2}^{r}\right.$ - E) for [Zn - L-lysinate-vitamin-PP] system, are given in Fig. 2 and 3(a,b), respectively. Parameter $\mathrm{Z}$ is calculated by the following equation [26, 27]:

$$
\mathrm{Z}=\operatorname{anti} \log \left\{\mathrm{n} \mathrm{F} / 2.303 \mathrm{RT}\left(\mathrm{E}_{1 / 2}^{\mathrm{r}}-\mathrm{E}\right)\right\}+\log \mathrm{i}_{\mathrm{d}}-\mathrm{i} / \mathrm{I}
$$

Values of kinetic parmeters are given in Table 3. It is obvious that $\alpha$ values varied from [ $\mathrm{Zn}{ }^{-}$L-lysinate $^{-}$vitamin-PP] 0.357 to 0.555 (about 0.50 ), and values of $\alpha$ for other systems were also about 0.50 , confirming that the 'transition state' lies midway between the dropping mercury electrode and the solution interface. The values of rate constant $(\mathrm{k})$ varying from 3.28 to $9.60 \mathrm{~cm} . \mathrm{sec}^{-1}$, confirm that the electrode processes are quasireversible. The values of diffusion coefficient (D), as determined by Ilkovic equation, [28], are as expected.
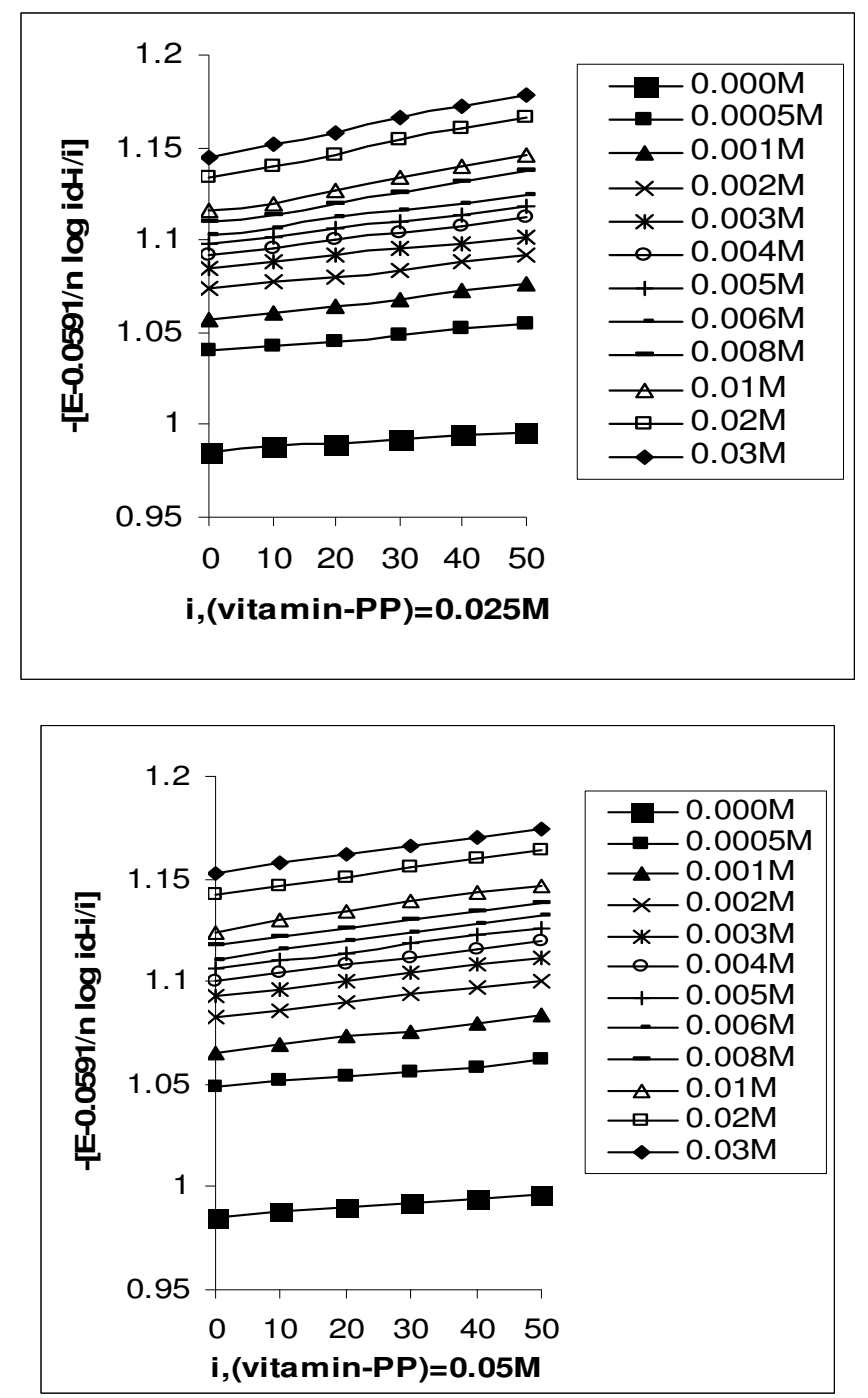

Figure 2. Plots between - [E-RT/nF log (id-i)/i] for Zn-L-lysinate-vitamin-PP system. 

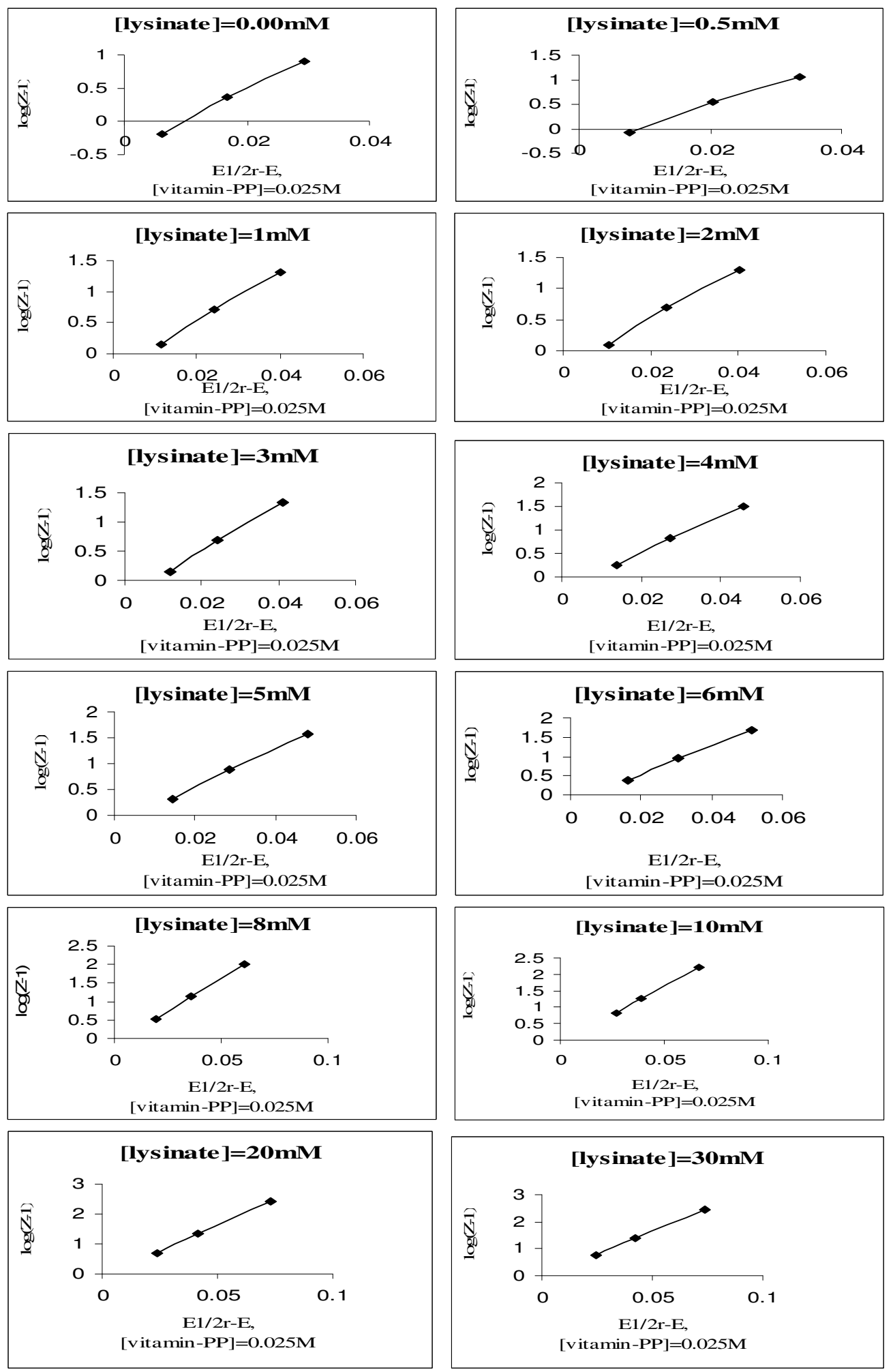

Figure 3a. Zn-L-lysinate-vitamin-PP system, plot of $\left(\mathrm{E}_{1 / 2}^{\mathrm{r}}-\mathrm{E}\right)$ versus $\lg (\mathrm{Z}-1)$. Y-axis $=\lg (\mathrm{Z}-1), \mathrm{X}$-axis $=\left(\mathrm{E}_{1 / 2}^{\mathrm{r}}-\mathrm{E}\right)$, vitamin-PP $=0.025 \mathrm{M}$ (fixed). 

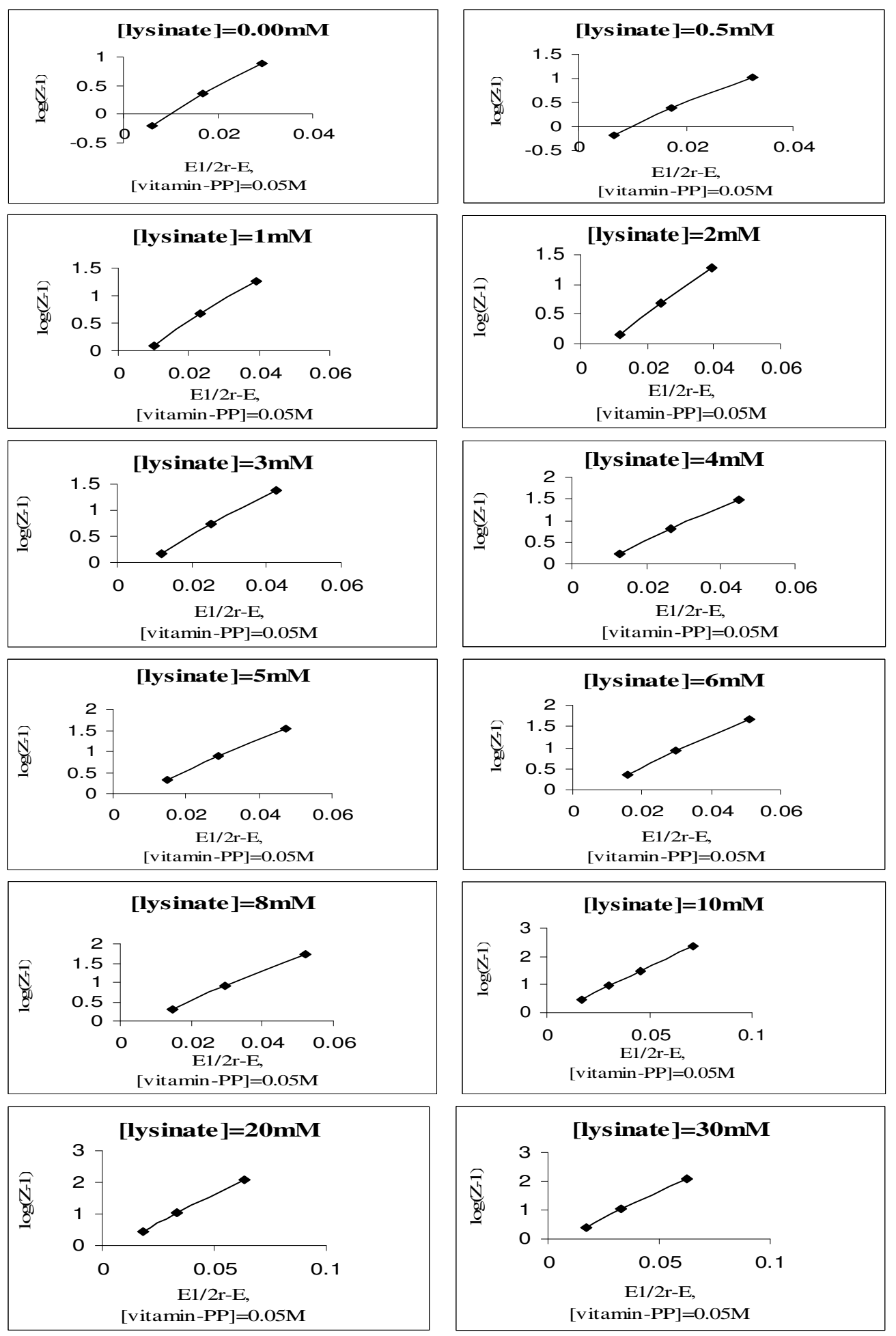

Figure 3b. Zn-L-lysinate-vitamin-PP system, plot of $\left(E_{1 / 2}^{r}-E\right)$ versus $1 g(Z-1)$. Y-axis $=\log (\mathrm{Z}-1), \mathrm{X}$-axis $=\left(\mathrm{E}_{1 / 2}^{\mathrm{r}}-\mathrm{E}\right)$, vitamin-PP $=0.05 \mathrm{M}$. 
Table 3. Kinetic parameters of [Zn-L-lysinate-vitamin-PP] system. $\mathrm{Zn}(\mathrm{II})=0.5 \mathrm{mM}, \mu=1.0 \mathrm{M} \mathrm{NaClO}_{4}, \mathrm{pH}=7.30 \pm 0.01$, Temperature $=25^{\circ} \mathrm{C}$.

\begin{tabular}{|c|c|c|c|c|c|c|c|c|c|c|c|c|}
\hline \multirow{2}{*}{$\begin{array}{l}\text { [L-lys. }] \\
\text { X } 10^{-3}\end{array}$} & \multicolumn{6}{|c|}{ [vitamin-PP] = 0.025 M (fixed) } & \multicolumn{6}{|c|}{$[$ vitamin-PP] $=0.05 \mathrm{M}$ (fixed) } \\
\hline & $\begin{array}{l}\left(\mathrm{E}_{1 / 2}\right)^{\mathrm{qr}}-\mathrm{V} \\
\text { vs. SCE }\end{array}$ & $\begin{array}{l}\text { Slope } \\
(\mathrm{mV})\end{array}$ & $\alpha$ & $\begin{array}{c}\lambda \\
\mathrm{s}^{-1 / 2}\end{array}$ & $\begin{array}{l}\mathrm{D}^{1 / 2} \times 10^{3} \\
\mathrm{~cm}^{2} \mathrm{~s}^{-1}\end{array}$ & $\begin{array}{l}\mathrm{kx} \times 10^{3} \\
\mathrm{~cm} \mathrm{~s}^{-1}\end{array}$ & $\begin{array}{l}\left(\mathrm{E}_{1 / 2}\right)^{\mathrm{qr}}-\mathrm{V} \\
\text { vs. SCE }\end{array}$ & $\begin{array}{l}\text { Slope } \\
(\mathrm{mV})\end{array}$ & $\alpha$ & $\underset{\mathrm{s}^{-1 / 2}}{\lambda}$ & $\begin{array}{l}\mathrm{D}^{1 / 2} \times 10^{3} \\
\mathrm{~cm}^{2} \mathrm{~s}^{-1 / 2}\end{array}$ & $\begin{array}{l}\mathrm{kx} \times 10^{3} \\
\mathrm{~cm} \mathrm{~s}^{-1}\end{array}$ \\
\hline 0.00 & 1.000 & 36 & 0.357 & 1.702 & 4.085 & 6.955 & 1.000 & 36 & 0.403 & 1.517 & 4.085 & 6.198 \\
\hline 0.50 & 1.043 & 37 & 0.486 & 1.517 & 4.019 & 6.098 & 1.054 & 36 & 0.357 & 1.910 & 4.019 & 7.677 \\
\hline 1.00 & 1.060 & 36 & 0.532 & 1.074 & 3.953 & 4.246 & 1.070 & 37 & 0.505 & 0.952 & 3.953 & 3.785 \\
\hline 2.00 & 1.077 & 38 & 0.464 & 1.205 & 3.888 & 4.685 & 1.087 & 37 & 0.406 & 1.702 & 3.887 & 6.618 \\
\hline 3.00 & 1.088 & 37 & 0.508 & 1.205 & 3.828 & 4.606 & 1.097 & 37 & 0.518 & 1.205 & 3.822 & 4.606 \\
\hline 4.00 & 1.095 & 38 & 0.508 & 1.074 & 3.756 & 4.034 & 1.105 & 37 & 0.532 & 1.074 & 3.756 & 4.034 \\
\hline 5.00 & 1.101 & 38 & 0.518 & 1.074 & 3.690 & 3.963 & 1.111 & 36 & 0.449 & 1.205 & 3.690 & 4.447 \\
\hline 6.00 & 1.106 & 37 & 0.555 & 0.957 & 3.624 & 3.469 & 1.115 & 36 & 0.403 & 1.517 & 3.624 & 5.498 \\
\hline 8.00 & 1.113 & 36 & 0.508 & 2.698 & 3.558 & 9.600 & 1.123 & 36 & 0.505 & 1.074 & 3.558 & 3.822 \\
\hline 10.00 & 1.119 & 36 & 0.535 & 1.074 & 3.492 & 3.751 & 1.128 & 37 & 0.546 & 0.853 & 3.492 & 2.979 \\
\hline 20.00 & 1.138 & 37 & 0.555 & 0.957 & 3.426 & 3.280 & 1.147 & 36 & 0.505 & 1.074 & 3.426 & 3.680 \\
\hline 30.00 & 1.149 & 38 & 0.518 & 0.957 & 3.426 & 3.280 & 1.157 & 36 & 0.571 & 0.853 & 3.426 & 2.923 \\
\hline
\end{tabular}




\section{Conclusion}

In the present paper, interaction of $\mathrm{Zn}$ between $\mathrm{L}$ - amino acids and vitamin-PP in $\mathrm{pH} 7.30 \pm 0.01$ was investigated using simple DC polarography. The results indicated that current voltage curves are quasireversible and diffusion controlled in $1.0 \mathrm{M} \mathrm{NaClO}_{4}$ at $\mathrm{pH}=7.30 \pm 0.01$ and at 25 and $35^{\circ} \mathrm{C}$. It is clear from the stability constant values of the complexes that vitamin-PP and amino acids used either singly or simultaneously might be effective to reduce the toxicity of metal in vivo. The negative values of $\Delta \mathrm{H}$ indicated the exothermic nature of the metalligands interaction. The complexes were not stable at higher temperature which was confirmed by the values of $\Delta \mathrm{G}$ and $\Delta \mathrm{S}$. Values of transfer coefficient $(\alpha)$ varied from 0.357 to 0.555 (0.50), showing that the 'transition state' behaves between oxidant and reductant response to applied potential and it lies in the midway between dropping mercury electrode and solution interface. The values of rate constant $(\mathrm{k})$ varied from 3.28 to $9.60 \mathrm{~cm} \cdot \mathrm{sec}^{-1}$ confirming the quasireversible nature of electrode processes.

\section{Acknowledgement}

The authors are thankful to Head of the Department of Chemistry, Dr. H. S. Gour University, Sagar for providing the laboratory facilities and DST, New Delhi and MAPCOST, Bhopal for financial support.

\section{References}

1. El-Said Asma, S.A. Zidan Amna, El-Meligy S. Mahmoud, A. Aref, Aly Omar, F. Mohamened, Synth. React. Inorg. Met. Org. Chem. 31 (2001) 633.

2. H.A. Ibrahim, M.A. Jeroudi, R.J. Baier, J. Perinatalo. 24 (2004) 482.

3. U. Duman, O.F. Dogan, J. Cardiac Surgery 21(2006) 523.

4. P. Malhotra, P.P. Subrayan, A. Chatterji, Council of Scientific \& Industrial Research (2005) 20050090480.

5. N. Hassan, M.Z. Janjua, J. Ayub. Med. Coll. Abbottabad. 13 (2001) 30.

6. L.S. Goodman, Gillman, The Pharmacological Basis of Therapeutics, McMillan Publisher Co., New York, 1980 p 1555.

7. B.M. Barker, D.A. Bender, Vitamin in Medicines, William Heinemann Medical Books Ltd., London, 1995 p 386.

8. M.D. Walker, D.R. Williams, J. Chem. Soc. Dalton Trans. (1974) 1186.

9. A.A. Khan, W.U. Malik, J. Indian Chem. Soc. 40 (1963) 565.

10. S.N. Chadar, F. Khan, J. Indian Chem. Soc. 83 (2006)1242.

11. F. Khan, Bull. Electrochem. 19 (2003) 283.

12. P.J. Gelling, Z. Electrochem. Ber. Bunsenges. Phys. Chem. 66 (1962) 477; 67 (1963) 799.

13. W.B. Schaap, D.L. McMaster, J. Am. Chem. Soc. 83 (1961) 4699.

14. R.C. Kapoor, B.S. Agarawal, Principles of Polarography, $1^{\text {st }}$ ed., Wiley Eastern Ltd: New Delhi, 1991 p. 71.

15. R. Dodke, F. Khan, J. Indian Chem. Soc. 70 (1993) 15.

16. S. Vajhallya, F. Khan, Bull. Chem. Soc. Japan 72 (1999)397.

17. S. Vajhallya, F. Khan, Bull. Electrochem. 16 (2000) 311. 
18. A.E. Martell, M. Calvin, Chemistry of Metal Chelate Compounds, $2^{\text {nd }}$ ed., Prenti ce Hall Inc., New York, 1952 p155.

19. B.V. Mrudula Rao, S.J. Swamy, P. Lingaish, Indian J. Chem. 24 (1985) 887.

20. B. Kozlevcar, N. Lah, I. Leban, I. Turel, P. Segedin, M. Petrik, F. Pohleven, A.J.P. White, D.J. Williams, G. Giesterd, Croat. Chem. Acta 72 (1999) 427.

21. B.L. Lewis, G.W. Luther, H. Lane, T.M. Church, J. Electroana. 7 (1995) 166.

22. J.C.F. Rossotti, H. Rossotti, The Determination of Stability Constants, McGraw Hill Book Co., London, 1961; F. Khan and A.V. Mahajani, J. Indian. Chem. Soc. 16 (1984) 165.

23. A.A. Al-Sarawy, Chem. Pap. 58 (2004)109.

24. M.S. Parihar, F. Khan, Ecle. Quim. 33 (2008) 29.

25. T. Atalay, E.G. Akgemci, Turk. J. Chem. 24 (2000) 89.

26. R. Tamamushi, N. Tanaka, Z. Phys. Chem. NeueFolge 39 (1963)117.

27. R. Tamamushi, K. Ishibashi, N. Tanaka, Z. Phys. Chem. NeueFolge 35 (1962) 211.

28. D. Ilkovic, Collec. Czech. Chem. Commun. 8 (1936) 13. 